\title{
Study of the Activity of Phospholipase A2 in Venom of the Transcaucasian Macrovipera Lebetina Obtusa
}

\author{
Shafiga Topchiyeva ${ }^{1}$, Elmar Babayev ${ }^{1}$, Huseyn Abiyev ${ }^{2}$ \\ ${ }^{1}$ Institute of Zoology of NAS of Azerbaijan, Baku \\ Adress: AZ1073,Baku,Sabail, Abbasgulu Abbaszadeh,115 \\ ${ }^{2}$ Institute of Radiation Problems of NAS of Azerbaijan, Baku \\ Address: AZ1143, Baku, 9, B. Vahabzadeh str.
}

\begin{abstract}
The activity of phospholipase A2 in the venom of the Transcaucasian Macrovipera lebetina obtusa, collected from viperas inhabiting in different regions of Azerbaijan in terms of pollution, was studied.

The lowest (30,2 IU / mg) was detected in the venom of Viperas collected in Sabirabad district, Karatuga village and the highest was detected in the venom of Viperas collected in Baku, s. Bina $(38,5 I U / m g)$.

As a result of experimental studies it follows that the activity of phospholipase in the venom collected in the vicinity of the Sabirabad district Karatuga village and Agsu district Garagoyunlu village, Gobustan district Childag village, Bina and Sumgait is $30.2 \pm 1.1 \mathrm{IU} / \mathrm{mg}$, $32.6 \pm 0.9 \mathrm{IU} / \mathrm{mg}, 34.5 \pm 0.8 \mathrm{IU} / \mathrm{mg}, 38.5 \pm 0.2 \mathrm{IU} / \mathrm{mg}$ and $36.1 \pm 0,8 \mathrm{IU} / \mathrm{mg}$, respectively.

Thus, the activity of phospholipase A2 in the venom of the Transcaucasian Viperas Macrovipera lebetina obtusa collected from snakes inhabiting different in the degree of contamination of the regions of Azerbaijan was studied.

The results of the experimental data can be used to determine the biological activity of the venom samples, including, for identification and standardization of the venom of the vipera.
\end{abstract}

Keywords- phospholipase A2, venom, snake, Macrovipera lebetina obtusa, heavy metals, enzyme activity.

\section{INTRODUCTION}

Among the huge number of biologically active substances of natural origin, one of the central places is occupied by animal poisons. Toxicity and enzymatic activity are the main characteristics of the biological activity of poisonous secretions. Venom toxicity is an integral characteristic and reflects the general effect of a toxin on a living organism, while snake venom enzymes have specific application points and mechanisms of action $[1,2,3]$.
Venomous snakes of genus Bungarus from family Elapidae are generally neurotoxin, but toxicity strongly depends on the particular species and regional origin of snakes. It should be noted that no proteomic data for B. multicinctus venom existed so far. In this venom, almost half $(45 \%)$ of the proteins by weight was represented by $\beta$-bungarotoxins, followed by three finger toxins (28\%) and phospholipases A2 (16\%), other proteins being present at the level of 1-3\%. In B. fasciatus venom, phospholipase A2 was the main component (71\%), followed by oxidase of 1-amino acids (8\%), acetyl cholinesterase $(5 \%)$ and metalloproteinases $(4 \%)$. Unexpectedly, extremely low amount of three finger toxins $(1 \%)$ was found in this venom. . Interestingly, the presence of complement depleting factor was observed in both venoms.

This concerns especially B.fasciatus venom with predominant content of phospholipases A2 and very low amount of three finger toxins [10].

Toxins from snake venom (among them the PLA2 and myotoxins) are neutralized by various compounds, such as antibodies and proteins purified from animal blood. Venomous and nonvenomous snakes have PLA2 inhibitory proteins, called PLIs, in their blood serum. One hypothesis that could explain the presence of these PLIs in the serum of venomous snakes would be self-protection against the enzymes of their own venom, which eventually could reach the circulatory system. However, the presence of PLIs in non-venomous snakes suggests that their physiological role might not be restricted to protection against PLA2 toxins, but could be extended to other functions, as in the innate immune system and local regulation of PLA2s [11].

Neuro- and myotoxicological signs and symptoms are significant clinical features of envenoming snakebites in many parts of the world. The toxins primarily responsible for the neuro and myotoxicity fall into one of two 
categories - those that bind to and block the post-synaptic acetylcholine receptors (AChR) at the neuromuscular junction and neurotoxic phospholipases A2 (PLAs) that bind to and hydrolyse membrane phospholipids of the motor nerve terminal to cause degeneration of the nerve terminal and skeletal muscle. The rationale behind the experimental studies on the pharmacology and toxicology of the venoms and isolated PLAs in the venoms is discussed, with particular reference to the way these studies allow one to understand the biological basis of the clinical syndrome. The review also introduces the involvement of PLAs in inflammatory and degenerative disorders of the central nervous system (CNS) and their commercial use in the food industry. It concludes with an introduction to the problems associated with the use of antivenoms in the treatment of neuro-myotoxic snakebite and the search for alternative treatments [12].

More proof to influence $\neg$ of factors of an environment there are venoms only after drying over steams chloride calcium or after liofils drying. Venom of a cobra, at storage on a cold in the soldered ampoule has kept toxicity more than 20 years. Snake venoms are thermostabilite and in the sour environment maintain heating to $120^{\circ} \mathrm{C}$ without loss of activity. The analysis of the biological activity of new proteins is a rather complex task due to a wide range of possible effects. Snake venoms that exhibit pronounced biological effects are complex protein mixtures. Well established targets at the organism or molecular levels are sufficient for a number of components of snake venoms, but the mechanisms of their action at the cellular level are far from understanding even for such well-studied proteins as alpha-neurotoxins or phospholipase A2. Proteins and peptides of snake venoms can influence all key processes of cell life. The components of venoms acting on transformed cells can prove to be valuable tools for the study of tumors, and can also be used to develop new diagnostic and medicinal products [4].

Phospholipase A2 (FLA2) is one of the main toxic components of venom of snakes and as a rule has various physiological properties, including neuro-, myo- and cardiotoxic. The biological activity of snake phospholipases is extremely diverse and depends on both the structure of the enzyme and the type of cells to which they affect. The content of this review is focused on the structural and functional features of the three types of components that predominate in snake venoms: trituration toxins, metalloproteinases and phospholipases $\mathrm{A}_{2}$.

Phospholipase A2 (FLA2) is a broad and heterogeneous family of enzymes that hydrolyze the ester bond of glycerophospholipids in the $\mathrm{Sn} 2$ position to form lysophospholipids and free fatty acids. Both these components participate in the generation of physiologically important secondary messengers. Arachidonic acid (AA) can serve as a precursor of eicosanoids (prostaglandins and leukotrienes), and lysophospholipids can be converted to lysophosphatidic acid or acetylated to form a platelet-activating factor (PAF) [5].

Phospholipase A2 is one of the main toxic components of venom of snakes, their biological properties are well studied. In contrast to mammalian phospholipase A2, many of them are toxic and exhibit a wide range of pharmacological effects $[6,7]$.

Experimental studies of the influence of the level of environmental pollution (heavy metals and radionuclides) on the enzymatic activity of the venom of the Transcaucasian vipera (Macrovipera lebetina obtusa Düigubsky, 1832) in the Absheron peninsula of Azerbaijan is undoubtedly an important and necessary step in the identification and standardization of zootoxins. Phospholipase A2 is widespread in nature and exists in a secreted and intracellular form. Secreted phospholipases A2 include enzymes of venoms of reptiles, arthropods and coelenterates, digestive enzymes of mammals [8]. Phospholipase A2 is the most studied enzyme from the group of phospholipases. It is allotted in its pure form from the venom of snakes, bees and from the tissue of the pancreas of animals.

Snake venoms are a complex mixture of components, and more than $90 \%$ of their dry weight consists of proteins with a large variety of enzymes, and a non-protein portion comprising carbohydrates, lipids, metals, free amino acids, nucleotides and others [13].

Phospholipases are a superfamily of enzymes that act on phospholipids in the cell membrane leading to their cleavage in fatty acids and lysophospholipids. Phospholipases $\mathrm{A}_{2}\left(\mathrm{PLA}_{2}\right)$ (EC 3.1.1.4) were the first phospholipases to be known and their discovery was based on observation of the action of pancreatic fluid of mammals and snake venom in the hydrolysis of phosphatidylcholine [14].

Interestingly, despite having no catalytic activity, the homologous $\mathrm{PLA}_{2} \mathrm{~S}$ Lys49 have a wide variety of pharmacological and/or toxic effects, including myotoxicity, cytotoxicity, antibacterial, antifungal, muscle necrotic and anticoagulant activities [15, 16, 17]. According to some authors, the main structural domain responsible for the toxic effect, particularly cytotoxic, in homologous Lys49-PLA ${ }_{2}$ is the C-terminal region (amino acids 115-129) [18].

Currently, antiserum composed of specific immunoglobulins is the only treatment for snake envenomation, but there are ongoing issues with availability, effectiveness and dosing $[\underline{19}, \underline{20]}$. These antivenoms neutralize the toxicity and lethality of specific 
venoms, but their administration is often related with significant clinical side effects $[\underline{21}, \underline{22}]$. Additionally, the production of antivenoms is associated with high costs related to animal maintenance and also comes across animal welfare concerns, which instigates the search for innovative products for snakebite therapy $[\underline{23}, \underline{24}]$.

The study of the activity of phospholipase $A_{2}$ is of great importance in determining the quality of snake venom and the standardization of zootoxin.

The study of biochemical, physic-chemical properties of snake venom depending on the degree of contamination of the territories of Azerbaijan is in great interest.

The purpose of this work was to study the activity of phospholipase $\mathrm{A}_{2}$ in the venom of Transcaucasian Macrovipera lebetina obtusa, collected from snakes in different territories of Azerbaijan depending on degree of contamination.

\section{MATERIALS AND METHODS}

The material of the research was samples of the poison of the viperas collected from snakes in different territories of Azerbaijan depending on the degree of contamination : from the vicinity of the Gobustan district Childag village, Baku city Bina settlement, Sumgait city, Sabirabad district Karatuga village and Agsu district Garagoyunlu village.

We have conducted summer field researches in areas of Azerbaijan. During the expedition catching of Viperas has been spent with a capture of venom. A part of venom of snake has been subjected to the analysis of heavy metals by a method of atom-absorption spectrometry (AAS-300 Perkin Elmer, USA).

Determination of the content of metal ions in snake venom samples collected from snakes from the studied territories of Azerbaijan was performed by atomic absorption spectroscopy with subsequent determination of enzymatic activity. The technique of study of viper venom by atomic absorption spectrometry consists in the following. An exact amount of snake venom in quantity of $20 \mathrm{mg}$ was placed in centrifuge tube, $10 \mathrm{ml}$ of solution $\mathrm{HCl}$ (1:1) was added and further a solution left in the thermostat at $400 \mathrm{C}$ at 1 hour. After that $2 \mathrm{ml}$ of $20 \%$ solutions $\mathrm{CCl} 3 \mathrm{COOH}$ was added, with the subsequent keeping during of 1 st hour at room temperature and centrifuged during 10 minutes at $1500 \mathrm{rpm}$. $\mathrm{Fe}, \mathrm{Cr}, \mathrm{Cu}$, $\mathrm{Cd}$ was detected in the filtrate. It is necessary to consider that fact that standard solutions should contain $5 \%$ trichloroacetic acid. Thus, we pick up optimum conditions for detecting $\mathrm{Fe}, \mathrm{Cr}, \mathrm{Cu}, \mathrm{Cd}, \mathrm{Zn}$ from trichloroacetic acid filtrate. For qualitative determination of concentration of investigated metals in bioobjects we constructed the graduated diagrams of determination of standard metals in coordinate's A-C. Under the graduated diagrams in coordinate's A-C concentration of detected elements was determined. Construction of graduated diagrams for detection of standard metals. For construction of graduated diagrams working standard solutions were entered serially into an air-acetylene flame of a burner, beginning from a solution with the minimum content of a detected element not less than four concentration, including the concentration close, to that which is expected in an analyzed solution. Each measurement repeated twice (not less than 2 times), at diagram construction average value was taken. The method of atom-absorption spectrophotometry (AAS-300, Perkin-Elmer) in vipera venom, caught from ecologically polluted sites of Absheron, defines the maintenance of heavy metals-pollutants.

The PLA2s activity in the venom was determined according to the titration method [5]. In the test tubes were placed $1 \mathrm{ml}$ solution $(0.05 \mathrm{~g}$ poison+ $0.9 \% \mathrm{KCl}+$ water), reagent $1(1 \mathrm{ml})(0.1 \mathrm{~g}$ albumin $+80 \mathrm{mg} 0,05 \mathrm{M}$ Tris buffer solution $\mathrm{pH} 8.0+2 \mathrm{ml} 0.05 \mathrm{M}$ Trilon B solution $+0.4 \mathrm{ml}$ of $50 \%$ solution of calcium chloride and the volume of solution was adjusted by $0.05 \mathrm{M}$ Tris buffer to $100 \mathrm{ml}$ ) and $1 \mathrm{ml} \mathrm{L-Alpha-lecithin} \mathrm{in} \mathrm{absolute}$ ethanol. Test tubes were placed in the thermostat at a temperature of $37 \mathrm{C}$ for $30 \mathrm{~min}$. Then $7 \mathrm{ml}$ of mixture was added into all tubes, shaken and stored at $20^{\circ} \mathrm{C}$ for 1 hour. Then $3 \mathrm{ml}$ of the upper layer from each tube was placed in $25 \mathrm{ml}$ conical flasks, added 5 drops of $0,2 \%$ thymol blue in $95 \%$ ethanol and used micro burette for titration with $0.01 \mathrm{M}$ of potassium hydroxide solution until the color of the solution changes from yellow to blue. The parallel control experiment was carried out, where water was taken instead of venom and then was done as described previously.

\section{RESULTS AND ITS DISCUSSION}

By using the method of atomic absorption spectroscopy, the content of metal ions in samples of snake venom collected from snakes from the studied territories of Azerbaijan was determined (Table 1) with the subsequent determination of enzymatic activity (Table 2).

Table.1: Data on the content of metal ions in the investigated samples of the venom of vipera, collected from snakes caught from the territory of Absheron region of Azerbaijan

\begin{tabular}{|c|c|c|c|c|}
\hline \multirow{2}{*}{ Territory } & \multicolumn{4}{|c|}{ Concentration of heavy metals, $\mathrm{mg} / \mathrm{kg}(\mathrm{M} \pm \mathrm{m})$} \\
\cline { 2 - 5 } & $\mathrm{Cr}$ & $\mathrm{Pb}$ & $\mathrm{Cd}$ & $\mathrm{Zn}$ \\
\hline $\begin{array}{c}\text { Gobustan district, Childag } \\
\text { village }\end{array}$ & - & $13.39 \pm 0.033$ & $1.9 \pm 0.200$ & $266.9 \pm 0.034$ \\
\hline
\end{tabular}




\begin{tabular}{|c|c|c|c|c|}
\hline $\begin{array}{c}\text { Sabirabad district, } \\
\text { Karatugai village }\end{array}$ & $87.0 \pm 0.049$ & $8.70 \pm 0.030$ & - & $269.0 \pm 0.076$ \\
\hline $\begin{array}{c}\text { Agsu district Garagoyunlu, } \\
\text { village. }\end{array}$ & $103.1 \pm 2.793$ & $8.13 \pm 6.560$ & $2.42 \pm 0.985$ & $250.0 \pm 3.063$ \\
\hline Baku city, s.Bina & - & $13.86 \pm 2.36$ & - & $354.7 \pm 8.604$ \\
\hline Sumgait city & - & $19,0 \pm 1.321$ & - & $377.6 \pm 8.402$ \\
\hline
\end{tabular}

It has been established by method of atom-absorbing spectrometry that the maintenance of heavy metals in venom of snake changes depending on degree of impurity of district of dwelling and corresponds: $\mathrm{Cr}(87.0-103.1), \mathrm{Pb}$ (8.13-19,0), Zn (250.0- 377.6), Cd $(1.9-2.42) \mathrm{mg} / \mathrm{kg}$.

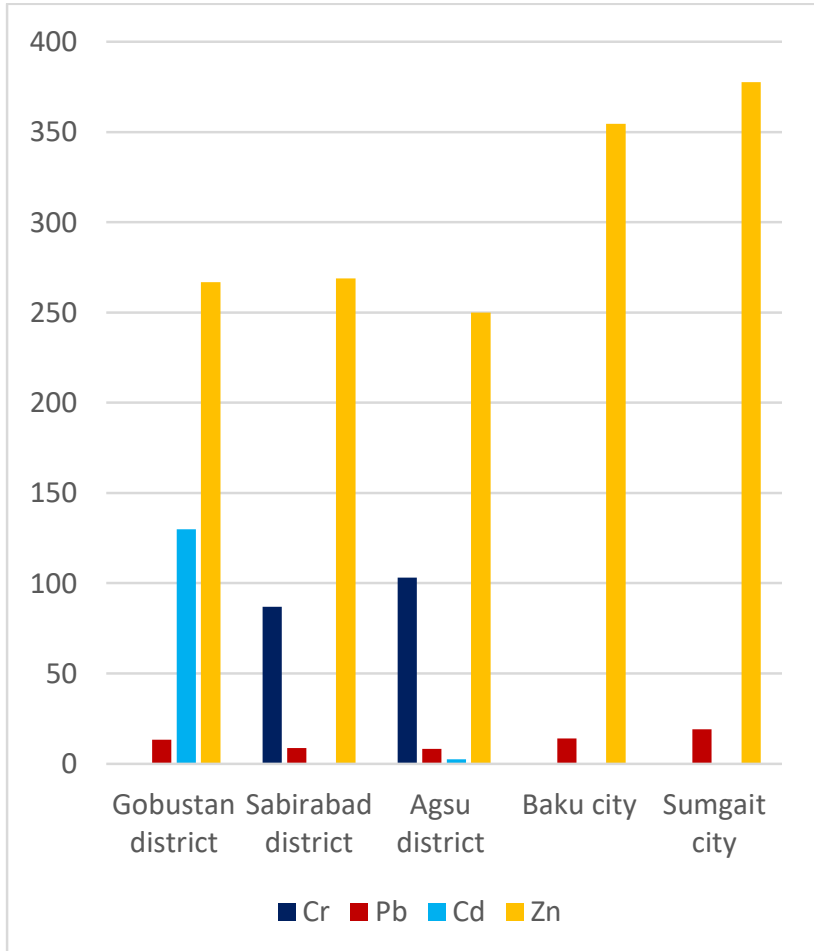

Fig.1. Dynamics of heavy metals of venom of the vipera, in the different researches district.

The results of the experimental data on the activity of phospholipase A2 in the samples of the venom of the vipera collected from snakes from different in the degree of contamination of the territories of Azerbaijan are shown in Table 2.

Table.2: The activity of phospholipase A2 in samples of the venom of vipera

(IU / mg)

\begin{tabular}{|l|c|}
\hline The territory of Azerbaijan & Enzyme activity (IU / mg) \\
\hline $\begin{array}{l}\text { Gobustan district, Childag } \\
\text { village }\end{array}$ & $34,5 \pm 0,8$ \\
\hline $\begin{array}{l}\text { Sabirabad district, Karatuga } \\
\text { village }\end{array}$ & $30,2 \pm 1,1$ \\
\hline $\begin{array}{l}\text { Agsu district, Garagoyunlu } \\
\text { village }\end{array}$ & $32,6 \pm 0,9$ \\
\hline
\end{tabular}

\begin{tabular}{|l|l|}
\hline Baku, s. Bina & $38,5 \pm 0.2$ \\
\hline Sumgait city & $36,1 \pm 0,8$ \\
\hline
\end{tabular}

It can be seen from the experimental data that the activity of phospholipase A2 in samples of venom collected from snakes from the village Childag of Gobustan district is $34.5 \pm 0.8 \mathrm{IU} / \mathrm{mg}$.

It follows from the table that the activity of phospholipase in the venom collected in the vicinity of the Sabirabad area Karatuga village and the Agsu district, Garagoyunlu village is $30.2 \pm 1.1 \mathrm{IU} / \mathrm{mg}$ and $32.6 \pm 0.9 \mathrm{IU} / \mathrm{mg}$, respectively. The activity of phospholipase $\mathrm{A} 2$ in the venom collected from snakes from the Childag village of Gobustan district is $34.5 \pm 0.8 \mathrm{IU} / \mathrm{mg}$. In the venom collected from snakes from the territory of Baku, s. Bina and Sumgait, the activity of the enzyme is $38.5 \pm 0.2 \mathrm{IU} /$ $\mathrm{mg}$, and $36.1 \pm 0.8 \mathrm{IU} / \mathrm{mg}$, respectively.

Thus, it can be stated that the lowest enzymatic activity was established in the samples of the vipera venom from the territory where the chromium and lead ions predominated, and the largest, where chromium and cadmium ions were absent at the same time.

At the same time, the activity of the enzyme in the venom collected in the vicinity of the Sabirabad area Karatuga village and Garagoyunlu village of Agsu district was 8.3, 5.9 and 5.9, 3.5 IU less than those in the samples collected from snakes from the territory of Baku, Bina and Sumgait. The enzymatic activity of phospholipase A2 in the venom of viperas caught in the vicinity of the Gobustan district Childag village is slightly lower, of the order of 4.0 and 1.6 IU than in the samples of the venom collected from snakes from the territory of Baku, Bina and Sumgait. This fact is explained by the presence of cadmium ions in samples of the poison of viperas caught in the vicinity of the Gobustan district Childag village.

From the foregoing and as a result of experimental studies it follows that the activity of phospholipase in the venom collected in the vicinity of the Sabirabad district Karatuga village and Agsu district Garagoyunlu village, Gobustan district Childag village, Bina and Sumgait is $30.2 \pm 1.1 \mathrm{IU} / \mathrm{mg}, 32.6 \pm 0.9 \mathrm{IU} / \mathrm{mg}, 34.5 \pm 0.8 \mathrm{IU} /$ $\mathrm{mg}, 38.5 \pm 0.2 \mathrm{IU} / \mathrm{mg}$ and $36.1 \pm 0,8 \mathrm{IU} / \mathrm{mg}$, respectively.

In conclusion, therefore, the PLA2s activity is one of the criteria for the quality of snake venom. The PLA2s is an indicator of the biological activity of snake venom. For 
this indicator, the venom from the surrounding area Sabirabad district, Karatuga village and Agsu district, Garagoyunlu village has a low biological activity.

The venom collected on apiaries of Baku, s. Bina, Sumgait city and Gobustan district, Childag village has a high biological activity. The results of the experimental data can be used for identification, standardization and determining the biological activity of honeybee venom. Thus, the activity of phospholipase A2 in the venom of the Transcaucasian Vipera Macrovipera lebetina obtusa collected from snakes inhabiting different in the degree of contamination of the regions of Azerbaijan was studied (Zagatala, Gobustan district, Childag village, Sabirabad district, Karatugai village, Agsu district Garagoyunlu, village, Baku city, s.Bina, Sumgait city)

\section{CONCLUSION}

Analyzing the presented results of our research we come to following generalizations. The PLA2s activity is one of the criteria for the quality of snake venom. The PLA2s is an indicator of the biological activity of snake venom.

1. It has been established by method of atom-absorbing spectrometry that the maintenance of heavy metals in venom of snake corresponds: $\mathrm{Pb}$ (49.13-134.9), $\mathrm{Zn}$ (360.8-863.6), Cd (1.6-1.9) mg/kg.

2. The lowest enzymatic activity was found in the samples of the vipera venom from the territory where the chromium and lead ions predominated, and the largest, where chromium and cadmium ions were absent, were found.

3. The negative influence of metal ions on the enzymatic activity of phospholipase A2 of vipera venom was revealed.

4. The PLA2s activity is one of the criteria for the quality of snake venom.

5. The PLA2s is an indicator of the biological activity of snake venom.

6. The venom from the surrounding area Sabirabad and Agsu (30.2 $\pm 1.1 \mathrm{IU} / \mathrm{mg})$ and (32.6 $\pm 0.9 \mathrm{IU} / \mathrm{mg})$, Bina, Sumgait and Gobustan, has 38,5 $\pm 0.2 \mathrm{IU} / \mathrm{mg}$, $36.1 \pm 0,8 \mathrm{IU} / \mathrm{mg}$ and 34,5 $\pm 0,8 \mathrm{IU} / \mathrm{mg}$, biological activity.

7. The venom collected on aria of Bina (38.5 IU/mg) has a high and Sabirabad (30,2 IU/mg) low biological activity.

8. The results of the experimental data can be applied in the identification, standardization and determination of the biological activity of the venom of the Transcaucasian vipera

\section{REFERENCES}

[1] Malenev A.L., Zaitseva O.V., Bakiev A.G. 2007. Toxicity of venom of common vipers from various sites of the range. Problems of Applied Ecology, pp. 259-261.

[2] Malenev A.L., Bakiyev A.G., Shurshina I.V., Zaitseva O.V., Zinenko A.I. 2005. The prototytic activity of the venom of common vipers from some populations of Russia and Ukraine. Zh. News of the Serrano S.M.T., Fox J.W. Snake Toxins and Hemostasis. Toxicon, , 45, pp. 951-1181.

[3] Orlov B.N., Gelashvili D.B. 1985. Zootoxinology (Poisonous animals and their poisons). Moscow "High School", pp.119-127.

[4] http: // fbras.ru/wpcontent/uploads/2016/02/Makarova-diation.

[5] Burke J.E., Dennis E.A. 2009. Phospholipase A2 biochemistry, Cardiovasc. Drugs Ther., pp. 49-59.

[6] Kudo I., Murakami M. 2002. Phospholipase A2 enzymes, Prostaglandins Other Lipid Mediat.,pp. 358.

[7] Kini R.M. 2003. Excitement ahead: structure, function and mechanism of snake venom phospholipase A2 enzymes, Toxicon, 42, pp. 827840.

[8] Bragina NA., ChupinV.V., Bulgakov V.G., Shalnev A.N. 1999. Lipid inhibitors of phospholipase A2, bioorganic chemistry, 25, 2, pp.83-96.

[9] Lakin G.F. 1990. Biometria. Moscow :"High School", pp. 178-182.

[10]Ziganshin R.H., Kovalchuk S.I., Arapidi G.P., Nguyen KC, Shoibonov BB, Tsetlin VI, Utkin Y.N. J. Toxicon. 1;107, pp. 197-209.

[11] Norival A. Santos-Filho, Claudia T. Santos. 2017. Alpha-type phospholipase $\mathrm{A}_{2}$ inhibitors from snake blood. Journal of Venomous Animals and Toxins including Tropical Diseases, 3, pp. 23-19.

[12]John B. Harris, Tracey Scott-Davey. 2013. Secreted Phospholipases $\mathrm{A}_{2}$ of Snake Venoms: Effects on the Peripheral Neuromuscular System with Comments on the Role of Phospholipases $\mathrm{A}_{2}$ in Disorders of the CNS and Their Uses in IndustryToxins (Basel), 5, 12, pp. 2533-2571.

[13] Santos-Filho N.A., Silveira L.B., Oliveira C.Z., Bernardes C.P., Menaldo D.L., Fuly A.L. 2008, A new acidic myotoxic, anti-platelet and prostaglandin $\mathrm{I}_{2}$ inductor phospholipase $\mathrm{A}_{2}$ isolated from Bothrops moojeni snake venom, Toxicon, 52(8), 908-17.

[14] Barros G.A., Pereira A.V., Barros L.C., Calvi S.A., Santos L.D. 2015. In vitro activity of phospholipase $\mathrm{A}_{2}$ and of peptides from Crotalus durissus terrificus venom against amastigote and promastigote forms of Leishmania (L.) infantum chagasi. J Venom Anim Toxins Incl Trop Dis.,21, p. 48.

[15] Murillo L.A., Lan C.Y., Agabian N.M., Larios S., Lomonte B. 2007.Fungicidal activity of a 
phospholipase- $\mathrm{A}_{2}$-derived synthetic peptide variant against Candida albicans. Rev Esp Quimioter, 20, 3, 330-3.

[16] Costa T.R., Menaldo D.L., Oliveira C.Z., SantosFilho N.A., Teixeira S.S., Nomizo A. 2008. Myotoxic phospholipases $\mathrm{A}_{2}$ isolated from Bothrops brazili snake venom and synthetic peptides derived from their C-terminal region: cytotoxic effect on microorganism and tumor cells. Peptides,29,10, pp. 1645-56.

[17] Lomonte B, Angulo, Y. 2010. Moreno E. Synthetic peptides derived from the C-terminal region of Lys49 phospholipase $\mathrm{A}_{2}$ homologues from viperidae snake venoms: biomimetic activities and potential applications. Curr Pharm Des.,16, 28, pp. 3224-30.

[18] Santos-Filho N.A., Boldrini-França J., SantosSilva L.K., Menaldo D.L., Henrique-Silva F., Sousa T.S. 2014. Heterologous expression and biochemical and functional characterization of a recombinant alpha-type myotoxin inhibitor from Bothrops alternatus snake. Biochimie, 105, pp. 119-28.

[19] Santos-Filho N.A., Sousa T.S., Boldrini-França J., Santos-Silva L.K., Menaldo D.L., Henrique-Silva F. 2016. BaltMIP, a recombinant alpha-type myotoxin inhibitor from Bothrops alternatus (Rhinocerophis alternatus) snake, as a potential candidate to complement the antivenom therapy. Toxicon, 124, 53-62.

[20] Prado N.D., Pereira S.S., da Silva M.P., Morais M.S., Kayano A.M., Moreira-Dill L.S. 2016. Inhibition of the myotoxicity induced by Bothrops jararacussu venom and isolated Phospholipases $\mathrm{A}_{2}$ by specific camelid single-domain antibody fragments. PLoS One, 11, 3, pp. 1513-1563.

[21] Bochner R. 2013. The international view of envenoming in Brazil: myths and realities. J Venom Anim Toxins Incl Trop Dis., 19, 1, p.29.

[22] Morais V.M., Massaldi H. 2009. Snake antivenoms: adverse reactions and production technology. J Venom Anim Toxins Incl Trop Dis.,15, 1, pp. 2-18.

[23] Zolfagharian H., Dounighi N.M. 2015. Study on development of Vipera lebetina snake anti-venom in chicken egg yolk for passive immunization. Hum Vaccin Immunother., 11, 11, pp. 2734-9.

[24] Krifi M.N., El Ayeb M., Dellagi K. 1999. The improvement and standardization of antivenom production in developing countries: comparing antivenom quality, therapeutical efficiency, and cost. J Venom Anim Toxins, 5, 2, pp. 128-41. 